\title{
Evaluation of Swelling Control Parameters for Stabilized Expansive Soil Buffer Layers under Pavement Embankment
}

\author{
Prof. Manoj Anaokar, Dr. Sharad Mhaiskar
}

\begin{abstract}
Flexible Pavements constructed on expansive soils like Black Cotton (B.C.) soils, suffer extensive damages due to volume changes and the resulting swelling pressures. The magnitude of the swelling pressure depends on various parameters but the moisture content variation which occurs during different seasons is the major cause of volume changes. To control this moisture variation, present study suggests to lay a lime stabilized buffer layer below the road embankment. This layer will be underlain by a mechanically stabilized layer with vertical cut-offs on either side. For the success of this methodology, it is necessary that, the swelling pressures of the stabilized layers of B.C. soil should be first lowered. The success of this protective methodology will also be depending upon the of moisture content at which these layers are to be compacted and also on the estimation of optimum percentage of lime to be used for stabilization. A combination of measures can be used to minimize the replacement of $\mathrm{BC}$ soil and its resulting impact on overlying structures especially pavements. The aim of the present work is to study these two parameters. Subsequently these properties will be used in recommending a combination of measures to minimize detrimental effects on overlying flexible pavements. Therefore, it is necessary to find out the relation between swelling pressure and those standard reference moisture contents such as Shrinkage Limit (SL) and Optimum Moisture Content (OMC) which being the properties of any given soil, will not vary with time. In the present study, therefore, SL and OMC are considered as the reference moisture contents for the soil and the variation in swelling pressures of the soil is studied at SL, OMC-2\%, OMC and $\mathrm{OMC}+2 \%$. The present study also, attempts to find out the possibility of using Shrinkage Limit value as a parameter in finding the optimum percentage of lime. X-Ray Diffraction tests were also carried out to study the effect of mineralogy on the observed swelling behaviour of the soils.
\end{abstract}

Index Terms - Expansive Soils, Flexible Pavements, Lime Stabilization, Optimum Lime Percentage; Swelling Pressure; X-Ray Diffraction

\section{INTRODUCTION}

Flexible Pavement layers are required to sustain stresses without experiencing excessive deflections. The development in technology led to sophisticated vehicle and aircraft designs and wheel configurations demanding highway and airfield pavements of equally good quality and durability. However, in their natural state the subgrade soils for these pavements, which are serving as a foundation, may not always be competent enough to bear the stresses thrust on them especially when the pavements are based on expansive soils.

Prof. Manoj Anaokar, Civil Engineering, SVKM's NMIMS (Deemed to be University)/ Mukesh Patel School of Technology Management \& Engineering, Mumbai-400056, India, +919869107573

Dr. Sharad Mhaiskar, Pro-Vice Chancellor, SVKM's NMIMS (Deemed to be University), Mumbai-400056, India
When water enters such expansive soil, there are volume changes and the soil swells and exerts an upward pressure on the pavements causing distress in the pavements. On loss of moisture, as expansive soil dries and shrinks, again subjected to volume changes. Cracks are developed in the soil. The depth of these cracks varies from a few millimeters to sometimes up to 1 to $1.5 \mathrm{~m}$. [1] Apart from the solutions like removal or partial replacement of soil as suggested by the codes [2]; [3] different researchers have also used the different stabilizing materials to control the swelling. Use of such materials is also common in concrete [4]. However, this study attempts to assess the relation between the geotechnical engineering properties like swelling pressure and reference moisture contents like SL and OMC. It also studies the effect of varying lime content on consistency limits and attempts to study the possibility of using SL as an indicative parameter in finding the optimum percentage of lime.

At present, related Indian Codes suggest that, for reducing the distress caused by volume changes due to expansive soils, the embankment for the pavement should not rest on expansive subgrades and the expansive soil be removed and replaced by Cohesive Non- Swelling (CNS) materials or Murom. But the availability of such material in sufficient quantity at reasonable costs poses problems in practical implementation of this solution and therefore, proves to be uneconomical, leading to a pressing need for some alternative solution.

\section{MATERIALS AND METHODS}

\section{A. Materials}

\section{The Expansive Black Cotton Soil}

Central India predominantly consists of Black Cotton Soil which is expansive in nature. Expansive Black Cotton soil samples for this study were collected from the three locations near Ahmednagar situated in Central Maharashtra, India. This region predominantly consists of Black Cotton Soil. These three locations are termed as location ' $A$ ', location ' $\mathrm{B}$ ' and Location ' $C$ '. The soil samples were collected from the depths $0.5 \mathrm{~m}$ and $1 \mathrm{~m}$ at these three locations. These depths are selected because it is observed in the earlier studies [1] that, the effective zone in which the volume changes are taking place is up to about $1 \mathrm{~m}$ depth. By Group Index method, which is used in certain countries to classify soils for pavement construction, the soil at location ' $A$ ' belongs to group A-7-5 whereas, the soils at locations ' $\mathrm{B}$ ' and ' $\mathrm{C}$ ' are of group A-7-6. All the six soils can be classified in $\mathrm{CH}$ group as per Indian Standard (IS) Soil classification. 


\section{B. Stabilizing Materials}

Several researchers have studied the effect of different stabilizing materials on various properties of expansive soils. Both the conventional materials like lime and fly ash, geosynthetics as well as non-conventional materials like rise husk ash, plastic strips, iron flakes, etc. have been tried by researchers. The effect of Lime [5], the effect of Fly Ash [6], [7], the effect of Cement [8], [9] have been studied by the researchers to find the variation in the properties of soils with different percentages of these stabilizing materials. Also, the non-conventional materials like Plastic Strips [10], Rice Husk Ash [11], Ground Granulated Blast Furnace Slag (GGBS) [12] have been studied. These researchers have studied the effect of stabilizers on the properties of soil like Unconfined Compressive Strength, California Bearing Ratio, Free Swell Index, Compaction Properties, etc. Some investigators also tried the use of Geosynthetics [13]; [14]. But geosynthetics do not provide the cost-effective solutions and they also require skilled human resource to execute the works. The continuous availability of non-conventional materials like Plastic Strips and Rice Husk Ash at any project location in sufficient quantities and the processing charges to convert them into a suitable form, for stabilization, restrict commercial and regular use of such materials on actual sites of pavement construction. Such research remains limited to the academic interest of the researchers. Use of Fly Ash and the relatively recent use of Ground Granulated Blast-furnace Slag (GGBS) as a stabilizing material is encouraging from the point of view of reduction in expansive properties of soil but again the availability of these materials, their costs in India and effectiveness in mixing technology used for their blending with soil, pose a problem in their regular use on site. The fine Fly Ash separated by electromagnetic separators in thermal power plants is available these days at considerable cost. Where the thermal power plants are not in the vicinity of the pavement projects, a huge transportation cost is also incurred. Use of Bottom Ash or Pond Ash is also tried by some investigators [15] but the optimum percentage of these materials to cause stabilization required for controlling the swelling nature of soil varies in the large range. The quality of Pond Ash available from place to place is varying and there is no control over the quality of this by-product as the Bottom Ash from the thermal plants is just dumped into the artificial ponds without any separation. It may also contain pieces of un-burnt coal which may affect the quality of subgrade material if, this ash is used for stabilization. Cement Stabilization is found useful but the increasing cost of cement and the processes involved in its manufacture being not environment friendly, the use of cement for stabilization is not an appropriate alternative. Though availability of pure lime is a problem in recent years, lime is relatively cheap compared to cement and use of lime as stabilizing material has already proved to be beneficial. Also, in the powdered form, its mixing is possible with the easily available equipment like Graders, Rotavators etc. The lime is available in Cement, to some extent in class ' F' Fly Ash (less than 10\%) which is available in India. But in the form of lime powder, lime is in its direct form and hence enables better chemical reactions with expansive clays compared to other stabilizing materials. Hence, in the present study, lime is used as stabilizing material.
The present work is divided in two parts. In the first part, the variation of swelling pressure is studied at the increasing moisture contents at SL, OMC, OMC-2\%, OMC and at $\mathrm{OMC}+2 \%$. This is necessary to find out at what moisture content the stabilizing layers shown in Fig. 1 can be compacted for the success of protective enclosure for controlling moisture ingress. In the second part, the effect of variation in lime content on Liquid Limit (LL), Plastic Limit (PL), Plasticity Index (PI) and Free Swell Index (FSI) is studied, as they are the traditional parameters for finding optimum percentage of lime. Also, the effect of variation in lime content on SL is studied to investigate the possibility of using SL as an indicative parameter in deciding the optimum percentage of lime. The tests and procedures adopted for carrying out these studies are discussed in the next section.

\section{Methods and Tests}

A series of laboratory experiments were performed on the soil samples initially, to classify the soils and also to assess the swelling potential of the expansive soils under consideration. Core Cutter Test [16] was initially performed on site to find out the field density and moisture content just after the monsoon rains were over. In order to find out the Maximum Dry Density (MDD) and Optimum Moisture Content (OMC), the Standard Proctor Tests with light weight compaction [17] were performed on the natural soil samples.

The Swelling Pressure Tests were performed as per [18] on all six soil samples by molding the samples at MDD and moisture content equal to SL, OMC-2\%, OMC and OMC+2\%.

The optimum percentage of lime stabilizer to be used for treating the subgrade soil on every pavement project site may differ from place to place depending on the mineralogical composition of the expansive soil. ASTM D-6276-99a suggests 'Eades and Grim Test' [19] was earlier used (this standard in withdrawn in July 2015 and not replaced) for finding the optimum percentage of lime in some of the countries. This test basically finds the alkalinity of the soil-lime solution at 2, 3, 4, 5 and $6 \%$ and is compared with the alkalinity of lime water, which is 12.45 . The percentage which gives the alkalinity close to 12.45 is considered as the optimum percentage of lime. This test is required to be performed at $25^{\circ} \mathrm{C}$ and at controlled humidity. As the site laboratories in India are not equipped with the facilities and controls on humidity and temperature for carrying out Eades and Grim Test, an alternative test is necessary as a reliable indicator of optimum percentage of lime to be used for lime stabilization which can be performed in any site laboratory and should be cost effective.

In several papers on studies on lime stabilized expansive soils it is observed that; the percentage of lime is taken from 2 to $6 \%$. The Eades and Grim Test also stated that, for finding the optimum percentage of lime the percentages to be considered are from 2 to $6 \%$ with an increment of $1 \%$. Therefore, in the present study Consistency Tests LL and PL [20] as well as SL [21] and FSI Tests [22] were performed with $0 \%$ (natural unstabilized soil), and then with lime stabilized soil with percentage of lime as $2 \%, 4 \%, 5 \%$ and $6 \%$ of lime by weight of oven dry expansive soils. The application of this study is given in the subsequent section which forms the basis for the further work. 


\section{THEORY}

The methodology of in-situ stabilization of expansive soil is, therefore, necessary for controlling expansiveness by improving engineering properties of these soils. But complete stabilization of soils up to $1.5 \mathrm{~m}$ depth, which is the effective zone of volume changes [1] is uneconomical. Therefore, the present codes [3] suggest the removal and replacement of soil up to a depth of $500 \mathrm{~mm}$. But the solution may not be practically and economically feasible due to the problems in availability of suitable materials. IRC 37-2012 [23], in its 'Special Points Relating to Design of Pavement on Expansive Soils', suggests the use of a buffer layer, acting like an interface layer. The present study suggests the use of $30 \mathrm{~cm}$ thick lime stabilized buffer layer below the embankment of pavement, projecting 1 to $1.5 \mathrm{~m}$ beyond the base of embankment and a $20 \mathrm{~cm}$ thick mechanically stabilized layer below this lime stabilized layer to prevent the moisture ingress in vertical direction. These two layers will together constitute the stabilization depth of $500 \mathrm{~mm}$ depth. Also, in order to reduce the moisture below the embankment due to the moisture ingress in horizontal direction, it is suggested to provide the vertical cuts-off on either side of the embankment below these stabilized layers up to a depth $1 \mathrm{~m}$ as shown in the Fig. 1. The width of such vertical cut-offs may be kept to a minimum of $1.5 \mathrm{~m}$ from the point of view of using the rollers to compact the vertical cut-offs, as minimum width of rollers available currently on sites is $1.2 \mathrm{~m}$. The swelling pressure versus moisture content relation is studied in the present work for finding the required density and moisture content at which the stabilized layers need to be compacted to achieve the control on moisture ingress in the natural B.C. soil area under the protective enclosure.

The success of stabilization depends on Optimum Percentage of Lime Stabilizer. At present, LL, PI and FSI are used as the parameters to find out the optimum percentage of lime. But, below the SL of the soil, no volume changes take place. SL is also an indicator of the shrinkage properties of soil. Therefore, the aim of the present work is, to study the possibility of using SL as an indicative parameter in deciding the optimum percentage of lime required for effective stabilization of B.C. soil.

The results obtained from laboratory studies and discussions thereon are presented in the subsequent section.

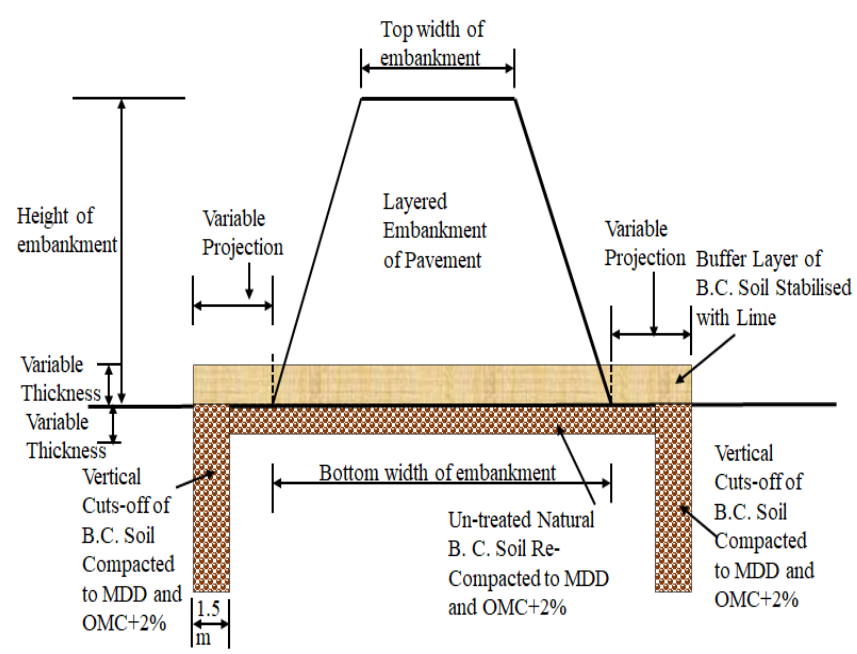

Figure 1 Details of Buffer Layer and Vertical Cut-offs under the Embankment

\section{RESUlTS AND DISCUSSION}

As the effect of expansiveness of the soil is primarily within top $1 \mathrm{~m}$ depth, hence in order to assess the changes of properties in this top $1 \mathrm{~m}$ depth, the disturbed samples were collected at each of these locations A, B and C at depths $0.5 \mathrm{~m}$ and $1.0 \mathrm{~m}$. Thus, these soils are termed as A-1, A-2, B-1, B-2 and C-1, C-2, with sample ' 1 ' referring to $0.5 \mathrm{~m}$ depth and sample '2' referring to $1.0 \mathrm{~m}$ depth.

Keeping in view the objectives of the present study, characterization of these soils through Grain Size Analysis by sieving, LL, PL, SL, FSI Tests, Swelling Pressure Tests and Compaction tests (to determine MDD and OMC) were conducted. These results are shown in Table 1.

Table 1 indicates that, all the soils are of $\mathrm{CH}$ group having LL around or greater than 70 and PI greater than 25. Generally, low values of SL indicate large volume change [1]. SL values for these soils are around or less than 20 and FSI values are more than 50, indicating these soils as highly expansive clayey soil as per IS 1498-1970 [24] .

The test results are discussed below: -

\section{A. Relation between Swelling Pressure and Moisture content}

The swelling pressure tests were conducted at moisture content equal to SL, OMC- $2 \%, \mathrm{OMC}, \mathrm{OMC}+2 \%$ with density of sample equal to MDD. The tests results are given in Table 2 and in Fig. 2. The swelling pressure decreases for the soils when moisture content increases from SL to OMC-2\%. Thereafter it increases up to $\mathrm{OMC}$ and becomes maximum at OMC. Thereafter, it decreases from OMC to OMC+2\%.

\section{B. Effect of lime content on the consistency limits and FSI values}

The effect of lime content on the consistency limits and FSI values was also studied and the results are presented ahead. These tests were carried out on soils with percentage of lime as $0 \%$ (unstabilized soil), $2 \%, 4 \%, 5 \%$ and $6 \%$.

The results are given in Table 3, Table 4, Table 5, Table 6, and Table 7 respectively and the graphical variations of these results are shown in Fig. 3, Fig. 4, Fig. 5, Fig. 6 and Fig. 7, respectively.

Table 1 Properties of Un-Stabilized Natural Soils

\begin{tabular}{|c|c|c|c|c|c|c|}
\hline Soil Sample & A-1 & A-2 & B-1 & B-2 & $\mathrm{C}-1$ & $\mathrm{C}-2$ \\
\hline $\begin{array}{c}\text { IS Soil } \\
\text { Classification } \\
\end{array}$ & $\mathrm{CH}$ & $\mathrm{CH}$ & $\mathrm{CH}$ & $\mathrm{CH}$ & $\mathrm{CH}$ & $\mathrm{CH}$ \\
\hline Liquid Limit (\%) & 99 & 78 & 66 & 71 & 93 & 89 \\
\hline Plastic Limit (\%) & 36 & 34 & 28 & 26 & 27 & 26 \\
\hline $\begin{array}{c}\text { Shrinkage Limit } \\
(\%)\end{array}$ & 18 & 23 & 20 & 21 & 11 & 12 \\
\hline $\begin{array}{c}\text { Plasticity Index } \\
(\%)\end{array}$ & 63 & 44 & 38 & 45 & 66 & 63 \\
\hline $\begin{array}{c}\text { Free Swell Index } \\
(\%)\end{array}$ & 188 & 66 & 111 & 90 & 138 & 180 \\
\hline $\begin{array}{c}\text { (Standard Proctor) } \\
\text { Maximum } \\
\text { Dry Density } \\
\left(\mathbf{k N} / \mathbf{m}^{3}\right) \\
(\text { Natural Soil) } \\
\end{array}$ & 14.22 & 17.07 & 15.01 & 15.89 & 14.02 & 16.09 \\
\hline $\begin{array}{c}\text { Optimum Moisture } \\
\text { Content }(\%) \\
\text { (Natural Soil) } \\
\end{array}$ & 24 & 32 & 27.5 & 27.5 & 22.5 & 19.5 \\
\hline
\end{tabular}


Table 2 Swelling Pressure $\left(\mathrm{kN} / \mathrm{m}^{2}\right)$ at Standard Reference Moisture Contents

\begin{tabular}{|l|c|c|c|c|c|c|}
\hline Soil Samples & A-1 & A-2 & B-1 & B-2 & C-1 & C-2 \\
\hline $\begin{array}{l}\text { At Shrinkage } \\
\text { Limit }\end{array}$ & 34.32 & 98.07 & 156.91 & 73.55 & 53.94 & 137.29 \\
\hline $\begin{array}{l}\text { At } \\
\text { OMC-2\% }\end{array}$ & 29.42 & 39.23 & 24.52 & 39.23 & 24.52 & 49.03 \\
\hline At OMC & 176.52 & 68.65 & 137.29 & 88.26 & 156.91 & 245.17 \\
\hline $\begin{array}{l}\text { At } \\
\text { OMC+2\% }\end{array}$ & 73.55 & 31.38 & 16.67 & 6.37 & 13.73 & 29.42 \\
\hline
\end{tabular}

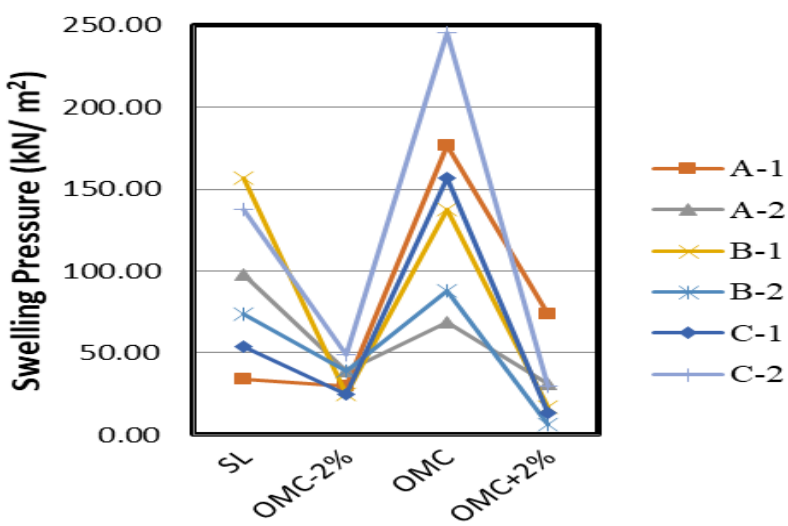

Figure 2 Relation between Moisture content and Swelling Pressure

Table 3 and Fig. 3 indicate a continuous reduction in LL values with increase in lime content from $0 \%$ to $4 \%$ but increase in $\mathrm{LL}$ at $5 \%$ lime and then again, a reduction in $\mathrm{LL}$ value at $6 \%$ of lime.

This can be attributed to the process of ion exchange taking place between negatively charged clay minerals and positively charged calcium compounds. It indicates that, initial addition of lime up to about $4 \%$ goes to satisfying the lime requirement to cause complete reaction between clay and calcium compounds, and hence, the LL goes on reducing.

Table 3 Variation in Liquid Limit with Lime Content

\begin{tabular}{|c|c|c|c|c|c|c|}
\hline Soil Sample & A-1 & A-2 & B-1 & B-2 & C-1 & C-2 \\
\hline \% Lime & & & & & & \\
\hline $\mathbf{0}$ & 99 & 78 & 66 & 71 & 93 & 89 \\
\hline $\mathbf{2}$ & 71 & 66 & 55 & 56 & 87 & 74 \\
\hline $\mathbf{4}$ & 70 & 57 & 52 & 50 & 71 & 65 \\
\hline $\mathbf{5}$ & 58 & 78 & 55 & 59 & 75 & 80 \\
\hline $\mathbf{6}$ & 55 & 56 & 48 & 45 & 58 & 57 \\
\hline
\end{tabular}

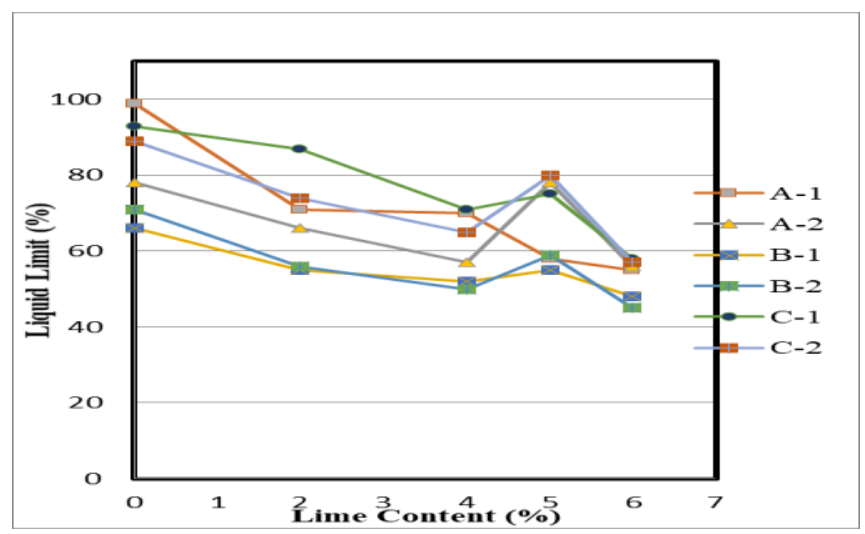

Figure 3 Variation in Liquid Limit with Lime Content

Table 4 and Fig. 4 indicate an increase in PL values at 2\% lime, then a decrease at lime content of $4 \%$, a slight increase at
$5 \%$ lime and then again, a reduction at $6 \%$ of lime. Initially, after adding lime at $2 \%$, the soil-lime mixture was soapy to touch while rolling the soil thread. This resulted in increase in PL. As lime content increases to $4 \%$, the calcium compounds are used for the cation exchange reaction between calcium compounds and clay minerals, and hence, as there is more demand for lime to complete the reaction, the soapy feel was not evident at $4 \%$ of lime. On adding more lime, at $5 \%$, the reaction between the clay minerals and calcium compounds seems to be completed as seen in case of Liquid Limit. As a result of the increased alkalinity, the PL increased. The excess lime after reaction at $6 \%$ causes the mixture to become friable leading to decreased PL and therefore, it was difficult to roll the thread of soil-lime mixture as it crumbled.

Table 4 Variation in Plastic Limit with Lime Content

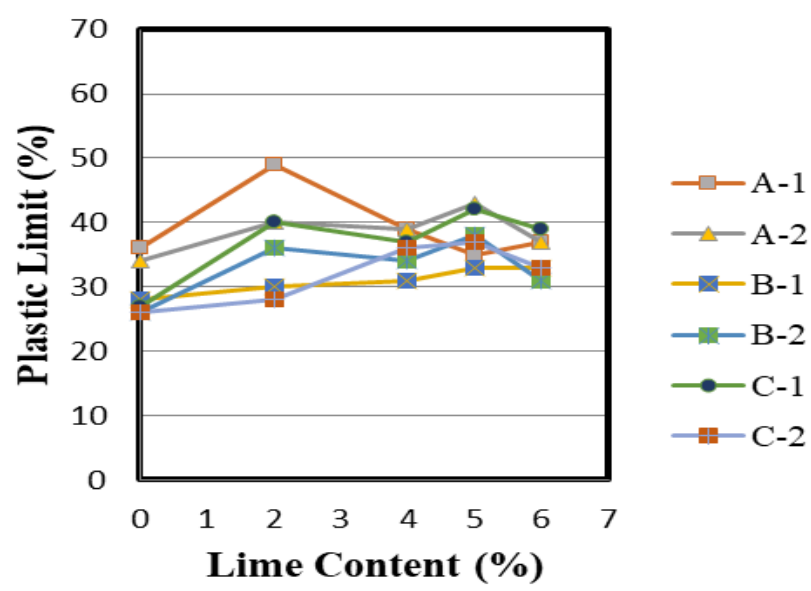

Figure 4 Variation in Plastic Limit with Lime Content

\begin{tabular}{|c|l|l|l|l|l|l|}
\hline Soil Sample & A-1 & $\mathbf{A - 2}$ & $\mathbf{B - 1}$ & $\mathbf{B}-2$ & $\mathbf{C - 1}$ & $\mathbf{C - 2}$ \\
\hline \% Lime & & & & & & \\
\hline $\mathbf{0}$ & 36 & 34 & 28 & 26 & 27 & 26 \\
\hline $\mathbf{2}$ & 49 & 40 & 30 & 36 & 40 & 28 \\
\hline $\mathbf{4}$ & 39 & 39 & 31 & 34 & 37 & 36 \\
\hline $\mathbf{5}$ & 35 & 43 & 33 & 38 & 42 & 37 \\
\hline $\mathbf{6}$ & 37 & 37 & 33 & 31 & 39 & 33 \\
\hline
\end{tabular}

Table 5 and Fig. 5 indicate a continuous reduction in PI values with increase in lime content from $2 \%$, but with little increase in PI at 5\% lime and then again, a reduction in PI value at $6 \%$ of lime. This is entirely in conformity with variations observed in LL and PL with increasing lime content.

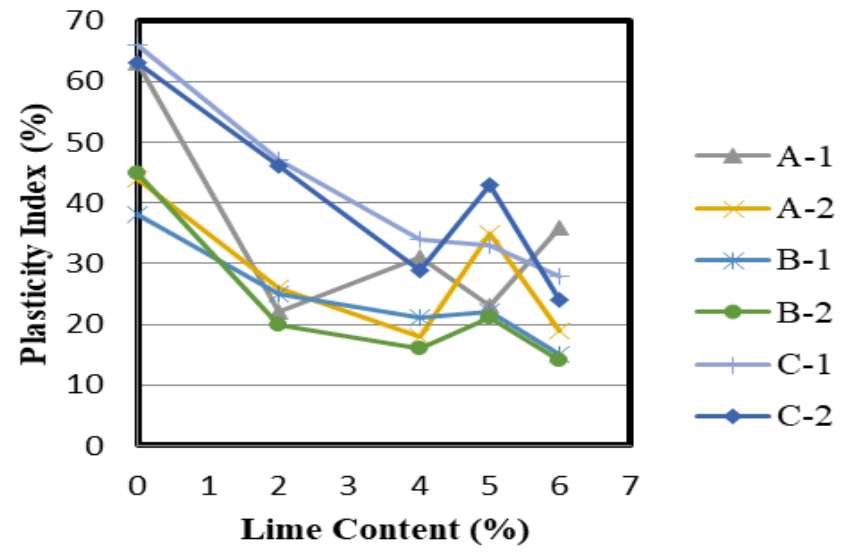

Figure 5 Variation in Plasticity Index 
Plasticity Index being the numerical difference between LL and PL, reflects the results obtained in LL-PL test.

Table 5 Variation in Plasticity Index with Lime Content

\begin{tabular}{|c|l|l|l|l|l|l|}
\hline Soil Sample & A-1 & A-2 & B-1 & B-2 & C-1 & C-2 \\
\hline \% Lime & & & & & & \\
\hline $\mathbf{0}$ & 63 & 44 & 38 & 45 & 66 & 63 \\
\hline $\mathbf{2}$ & 22 & 26 & 25 & 20 & 47 & 46 \\
\hline $\mathbf{4}$ & 31 & 18 & 21 & 16 & 34 & 29 \\
\hline $\mathbf{5}$ & 23 & 35 & 22 & 21 & 33 & 43 \\
\hline $\mathbf{6}$ & 36 & 19 & 15 & 14 & 28 & 24 \\
\hline
\end{tabular}

Therefore, the normal trend seen in case of PI is of reduction with increase in percentage of lime till 5\%. As LL and PL both are increasing slightly at $5 \%$ lime, hence PI also shows the increase at $5 \%$ for the reasons already stated and thereafter, the PI value shows reduction in almost all the soils. Only soil A-1 shows increase in PL and therefore PI value at $6 \%$ lime. This can be attributed to the fact that, the soil A-1 has mineralogical composition slightly different from other soils as shown in Table 8 of mineralogical composition. This soil consists of additional mineral of Gypsum which may increase the Plasticity and hence there is increase in PI value at $6 \%$.

Table 6 and Fig. 6 indicate a continuous increase in SL values from $2 \%$, with highest SL occurring at $5 \%$ lime and then again, a reduction in SL value at $6 \%$ of lime. This can be compared with the results of LL and PL which also show that, possibly the reactions of cation exchange are getting satisfied at $5 \%$ of lime in case of this given soil. SL is maximum at $5 \%$ indicating that, the swelling nature will be least at $5 \%$. This trend is even observed in case of soil A-1. Therefore, it can be concluded that, SL can be used as an indicative parameter for deciding the optimum percentage of lime.

Table 6 Variation in Shrinkage Limit with Lime Content

\begin{tabular}{|c|c|c|c|c|c|c|}
\hline Soil Sample & A-1 & A-2 & B-1 & B-2 & C-1 & C-2 \\
\hline \% Lime & & & & & & \\
\hline $\mathbf{0}$ & 18 & 23 & 20 & 21 & 11 & 12 \\
\hline $\mathbf{2}$ & 33 & 25 & 39 & 36 & 17 & 36 \\
\hline $\mathbf{4}$ & 49 & 37 & 47 & 37 & 42 & 59 \\
\hline $\mathbf{5}$ & 57 & 52 & 49 & 41 & 58 & 65 \\
\hline $\mathbf{6}$ & 43 & 34 & 35 & 32 & 35 & 40 \\
\hline
\end{tabular}

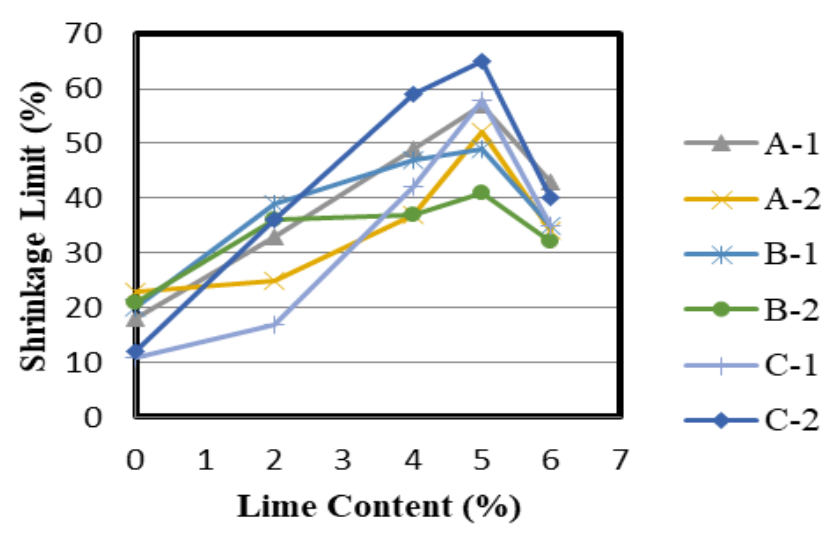

Figure 6 Variation in Shrinkage Limit with Lime Content

Table 7 and Fig. 7 indicate a sharp reduction in FSI values at $2 \%$ for all the soils, thereafter the FSI values are increasing up to $4 \%$ lime content for all the soils except soil A-1.

Table 7 Variation in Free Swell Index with Lime Content

\begin{tabular}{|c|c|c|c|c|c|c|}
\hline $\begin{array}{c}\text { Soil } \\
\text { Sample }\end{array}$ & A-1 & A-2 & B-1 & B-2 & C-1 & C-2 \\
\hline \% Lime & & & & & & \\
\hline 0 & 188 & 66 & 111 & 90 & 138 & 180 \\
\hline 2 & 78 & 50 & 71 & 64 & 63 & 92 \\
\hline 4 & 100 & 46 & 67 & 43 & 71 & 71 \\
\hline 5 & 125 & 83 & 80 & 82 & 110 & 100 \\
\hline 6 & 87 & 43 & 58 & 54 & 63 & 91 \\
\hline
\end{tabular}

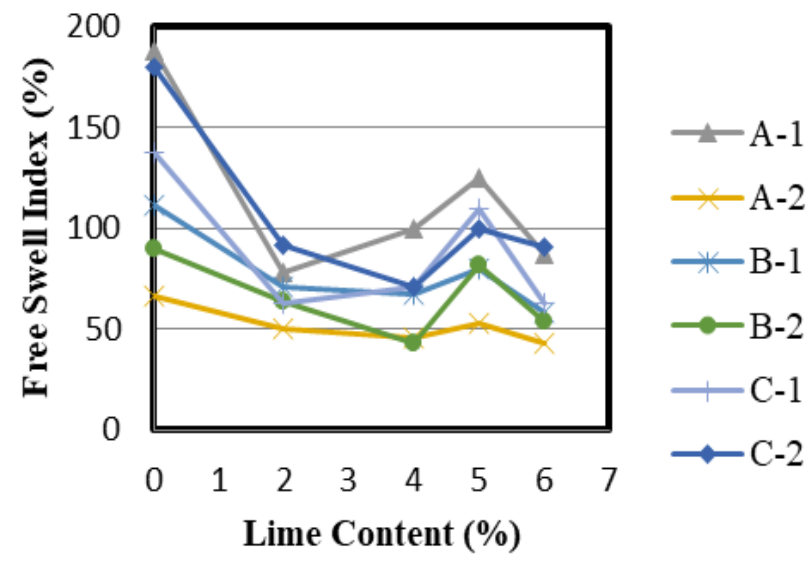

Figure 7 Variation in Free Swell Index

This difference in behaviour is possibly due to the presence of Gypsum which is only present in soil A-1 (Table 8). Then the values are again increasing sharply at $5 \%$ of lime for all the soils and thereafter, reduce at $6 \%$ lime content for all the soils. This shows that, at the $5 \%$ all the soils have consistent increase in their FSI values before they drop finally, indicating some specific behaviour at $5 \%$ of lime which is consistent with the behaviour of soils at $5 \%$ in case of LL, PI and SL.

The above results also indicate that, SL can be used as an indicative parameter for deciding the optimum percentage of lime required to prepare the design mix for stabilization.

The slightly different behaviour of sample A-1 suggested the possible influence of mineralogy. Therefore, it was thought appropriate to study the effect of presence of minerals on the swelling pressure of the soil. Hence, X-Ray Diffraction (XRD) tests were performed at IIT Bombay on all the six soil samples. The results of these tests are shown in Table 8 . Calcite $\left(\mathrm{CaCO}_{3}\right)$, Quartz $\left(\mathrm{SiO}_{2}\right)$, Albite $\left(\mathrm{NaAlSi}_{3} \mathrm{O}_{8}\right)$ and Montmorillonite $\mathrm{Na}_{0.2} \mathrm{Ca}_{0.1} \mathrm{Al}_{2} \mathrm{Si}_{4} \mathrm{O}_{10}(\mathrm{OH})_{2}\left(\mathrm{H}_{2} \mathrm{O}\right)_{10}$ are the common minerals in all the six soils. Zeolite $\left(\mathrm{NaAlSi}_{2} \mathrm{O}_{6}\right.$ $\mathrm{H}_{2} \mathrm{O}$ ) and Gypsum $\left(\mathrm{CaSO} .2 \mathrm{H}_{2} \mathrm{O}\right)$ are present only in Soil A-1 and not in rest of the soils.

Whereas Ilmenite-Hemetite $\left(\mathrm{FeTiO}_{3}\right.$-FerOr) solution and Diopside $\left(\mathrm{MgCaSi}_{2} \mathrm{O}_{6}\right)$ which are present in B-1 and C-1 are not present in rest of the soils. The Soils B-1, B-2, C-1 and $\mathrm{C}-2$ are collected from the fields which are under irrigated farms whereas, Soil A-1 is collected from the outer side of border of farm field which was the side of drainage (stream) of the highway. The Soil Samples A-2, B-1, B-2 and C-1, C-2 on the other hand were collected from inside of the farm fields therefore seem to be residual soils deposits whereas, Soil deposited near the surface at A-1 seems to be a transported soil being closer to stream and thus possesses Gypsum and Zeolite which are not present in the rest of the soils. 
Table 8 Presence of Minerals in Soils

\begin{tabular}{|c|c|c|c|c|c|c|}
\hline Soil Type & A-1 & A-2 & B-1 & B-2 & C-1 & C-2 \\
\hline Calcite & Yes & Yes & Yes & Yes & Yes & Yes \\
\hline Quartz & Yes & Yes & Yes & Yes & Yes & Yes \\
\hline Montmorillonite & Yes & Yes & Yes & Yes & Yes & Yes \\
\hline Albite & Yes & Yes & Yes & Yes & Yes & Yes \\
\hline Zeolite Rho & Yes & No & No & No & No & No \\
\hline Gypsum & Yes & No & No & No & No & No \\
\hline $\begin{array}{c}\text { Ilmenite-Hemetite } \\
\text { Solution }\end{array}$ & No & No & Yes & No & Yes & No \\
\hline Diopside & No & No & Yes & No & Yes & No \\
\hline
\end{tabular}

The properties governing swelling are given in Table 9. The results of swelling pressure tests are given for samples molded at Maximum Dry Density (MDD) and Optimum Moisture Content (OMC) and also for samples which were cast at MDD-OMC-2\% and also at MDD-OMC+2\%. FSI values are also given.

From Table 9 it can be seen that, FSI and swelling pressure at $\mathrm{OMC}$ - the two important indicators of expansive behaviour - are showing good correlation. For example, swelling pressures at $\mathrm{OMC}$ increase from $68.65 \mathrm{kN} / \mathrm{m}^{2}$ for A-2 to $245.17 \mathrm{kN} / \mathrm{m}^{2}$ for $\mathrm{C}-2$.
Earlier studies (Ghosh and Subbarao, 2006) show that, Gypsum reacts with the lime present in the Fly Ash and thus causes the stabilization of the Fly Ash. Similarly, Gypsum will react with the lime present naturally in the B.C. soil A-1, in the form of $\mathrm{CaCO}_{3}$ causing its stabilization. Therefore, the reduction in swelling pressure of the soil A-1 is observed in spite of having greater FSI value as compared to soil C-2 which has FSI close to that of the soil A-1. From Table 9 it can be seen that, the swelling pressure values at $\mathrm{OMC}$, which are maximum and hence critical, are mainly governed by the percentage of fines and the percentage of expansive clay particles finer than 2 microns. As in clay minerals there are different clay minerals like Kaolinite, Illite, etc. in addition to Montmorillonite, all of which are not responsible for swelling the soil. Even a small increase in percentage of fines increases the swelling pressure by large amount. This can be attributed to the fact that, as the percentage of fines increases, the permeability decreases, which causes increase in capillarity of water and the accompanying increase in suction pressures leading to increase in swelling pressure magnitude. Therefore, from the above discussion, it can be inferred that, for commenting on the magnitude of swelling pressure, FSI

Table 9 Properties of Expansive Soils Governing Swelling

\begin{tabular}{|c|c|c|c|c|c|c|}
\hline Soil Sample & A-1 & A-2 & B-1 & B-2 & C-1 & $\mathrm{C}-2$ \\
\hline Grain Size Analysis & $\begin{array}{c}\text { Gravel } 2 \% \\
\text { Sand } 15 \% \\
\text { Silt \& Clay } \\
83 \% \\
\text { (Silt } 45 \% \text {, Clay } \\
38 \% \text { ) } \\
\end{array}$ & $\begin{array}{c}\text { Gravel } 1 \% \\
\text { Sand } 38 \% \\
\text { Silt \& Clay } \\
61 \% \\
\text { (Silt } 42 \% \\
\text { Clay 19\%) } \\
\end{array}$ & $\begin{array}{c}\text { Gravel } 0 \% \\
\text { Sand } 29 \% \\
\text { Silt \& Clay } \\
71 \% \\
\text { (Silt 33\% } \\
\text { Clay 38\%) } \\
\end{array}$ & $\begin{array}{c}\text { Gravel } 3 \% \\
\text { Sand } 23 \% \\
\text { Silt \& Clay } \\
74 \% \\
\text { (Silt } 49 \% \\
\text { Clay 25\%) }\end{array}$ & $\begin{array}{c}\text { Gravel } 2 \% \\
\text { Sand } 16 \% \\
\text { Silt \& Clay } \\
82 \% \\
\text { (Silt 50\%, } \\
\text { Clay 32\%) } \\
\end{array}$ & $\begin{array}{l}\text { Gravel } 1 \% \\
\text { Sand } 14 \% \\
\text { Silt \& Clay } \\
85 \% \\
\text { (Silt 54\%, } \\
\text { Clay 31\%) }\end{array}$ \\
\hline IS Soil Classification & $\mathrm{CH}$ & $\mathrm{CH}$ & $\mathrm{CH}$ & $\mathrm{CH}$ & $\mathrm{CH}$ & $\mathrm{CH}$ \\
\hline Free Swell Index (\%) & 188 & 66 & 111 & 90 & 138 & 180 \\
\hline $\begin{array}{l}\text { Swelling Pressure }\left(\mathrm{KN} / \mathbf{m}^{2}\right) \\
\text { at OMC-2 }\end{array}$ & 29.42 & 39.23 & 24.52 & 39.23 & 24.52 & 49.03 \\
\hline $\begin{array}{l}\text { Swelling Pressure }\left(\mathrm{KN} / \mathrm{m}^{2}\right) \\
\text { at OMC }\end{array}$ & 176.52 & 68.65 & 137.29 & 88.26 & 156.91 & 245.17 \\
\hline $\begin{array}{l}\text { Swelling Pressure }\left(\mathrm{KN} / \mathrm{m}^{2}\right) \\
\text { at } \mathrm{OMC}+2 \%\end{array}$ & 73.55 & 31.38 & 16.67 & 6.37 & 13.73 & 29.42 \\
\hline
\end{tabular}

values or degree of expansiveness of the soil, the factors like percentage finer than 75 microns or percentage finer than 2 microns and if available, then the mineral composition of soil should also be taken together into account and degree of expansiveness or magnitude of swelling pressure should not be referred to any of these factors in isolation.

The present study is about the effect of lime content on consistency and swelling properties of expansive soils. For the soils studied herein, one could estimate the optimum lime content to be used for obtaining desirable shrinkage characteristics of the lime stabilized buffer layer below the embankment and also the compaction characteristics of the mechanically stabilized layer underlying it.

For controlling the moisture variations below the embankment which cause volume changes, this study suggests a protective enclosure below the embankment as shown in Fig. 1, in the form of lime stabilized interface buffer layer and mechanically stabilized layer below it, projecting beyond the embankment to prevent moisture ingress in

vertical direction. Vertical Cuts-off can be provided to prevent the moisture ingress in the horizontal direction. The thickness of these layers and depth of vertical cuts-off need further detailed studies based on the flow analysis with various dimensions of these protective cover for optimization of these dimensions for getting better control on moisture variation.

\section{CONCLUSION}

Following observations are made from the present study: -

1) The relation between swelling pressure and moisture content can be obtained at the standard reference moisture contents at SL, OMC-2\%, OMC and OMC $+2 \%$. These moisture content values are not affected by seasonal variation as they are the reference properties of soil. Therefore, they can be used to study the relation between swelling pressure and moisture content.

2) Swelling pressure magnitude is greatly affected by the variation in percentage of fines (finer than 75 microns), percentage of particles finer than 2 microns consisting of swelling and non-swelling clay minerals and certain other minerals like Gypsum, affecting the swelling. Therefore, while commenting on the magnitude of swelling pressure, FSI values or degree of expansiveness of the soil, mainly 
percentage finer than 75 microns and percentage finer than 2 microns should be taken together into account and if mineral composition test results are available, then they should be additionally considered as the factors affecting swelling. But any of these factors should not be referred in isolation for deciding the degree of expansiveness of the soil.

3) The results of variation in LL, PI and FSI with variation in lime percentage are consistent with those of variation in SL at the same percentage of lime.

4) Therefore, this study suggests that, SL can be used as an indicative parameter for deciding the optimum percentage of lime, as this test is simple to perform and cost effective as well as can be performed in any site laboratory. The percentage of lime yielding maximum SL value can be considered as optimum percentage of lime.

5) The Gypsum and Zeolite present in the soil seem to affect the values of PL and PI but does not seem to effect SL values.

\section{ACKNOWLEDGMENT}

The authors are thankful to Professor G. Venkatachalam, Professor Emeritus (Adjunct), NMIMS, Mumbai and Formerly Professor, Civil Engineering, IIT Bombay, Mr. Dilip Karandikar, Senior Geotechnical Consultant and Dr. R. A. Hegde, Professor and Head, Civil Engineering Department, MPSTME, NMIMS, Mumbai for their valuable comments and suggestions as well as to Mr. Pramod Bongirwar, Retired Secretory PWD, Government of Maharashtra, India, for giving practical insights.

\section{REFERENCES}

[1] R. K. Katti, "Search for solutions to problems in black cotton soils," in First IGS Annual Lecture, 20th Annual General Session, 1978, no. December, pp. 1-58.

[2] Indian Road Congress(IRC-36), "IRC-36:recommended practice for the construction of earth embankments for road works." IRC, New Delhi, India, pp. 1-24, 1970.

[3] S. MoRTH, "MoRTH Specification for Roads and Bridges 2001.” pp. 1-100, 2001.

[4] S. Mhaiskar and D. Naik, "Studies on correlation between flexural strength and compressive strength of concrete," Indian Concr. J., vol. 86, no. 9, pp. 1-6, 2012.

[5] T. Y. Elkady, A. M. Al-mahbashi, and T. O. Al-refeai, "Stress-dependent soil-water characteristic curves of lime-treated expansive clay," J. Mater. Civ. Eng., vol. 27, no. 9, pp. 1-9, 2013.

[6] B. R. Phanikumar and R. S. Sharma, "Volume change behavior of fly ash-stabilized clays," J. Mater. Civ. Eng., vol. 19, no. 1, pp. 67-75, 2007

[7] Y. Heping, L. I. N. Liping, X. Jie, and Z. Wentaool, "Analysis of the Improvement Effect of Expansive Soil through the Soil-water Characteristic Curve," J. Highw. Transp. Res. Dev., vol. 6, no. 4, pp. 36-41, 2012.

[8] W. S. Guthrie, M. S. Shea, and D. L. Eggett, "Hydraulic conductivity of cement-treated soils and aggregates after freezing," Cold Reg. Eng. 2012 Sustain. Infrastruct. Dev. a Chang. Cold Environ., pp. 93-103, 2012.

[9] J. O. Kolawole, "Stabilisation of tropical black clay with cement and pulverised coal bottom ash admixture," Adv. Unsaturated Geotech., pp. 289-302, 1996.

[10] M. Neopaney, K. Wangchuk, S. Tenzin, Ks. Chamberlin, and A. Professor, "Stabilization of soil by using plastic wastes," Int. J. Emerg. trends Eng. Dev., vol. 2, no. 2, pp. 461-466, 2012.

[11] A. Kuity and T. K. Roy, "Utilization of geogrid mesh for improving the soft subgrade layer with waste material mix compositions," Procedia - Soc. Behav. Sci., vol. 104, pp. 255-263, 2013.

[12] A. K. Sharma and P. V. Sivapullaiah, "Improvement of strength of expansive soil with waste granulated blast furnace," in GeoCongress 2012, 2012, pp. 3920-3928.

[13] D. Chen, T. Scullion, F. Hong, and J. Lee, "Pavement swelling and heaving at state highway 6," J. Perform. Constr. Facil., vol. 25, no. August, pp. 326-335, 2011.

[14] K. Ravi, S. K. Dash, S. Vogt, and G. Braeu, "Behaviour of geosynthetic reinforced unpaved roads under cyclic loading," Indian Geotech. J., vol. 44, no. 1, pp. 77-85, 2014

[15] A. Bera, "Effect of pond ash content on engineering properties of fine grained soil," Indian Geotechnical Conference. pp. 16-18, 2010.

[16] BIS, "IS 2720 Method of Test for Soils:Part29 Determination of Dry Density of Soils In-Place by The Core-Cutter Method.” pp. 1-9, 1975.

[17] BIS, "IS 2720 methods of test for soils:part 7 determination of water content-dry density relation using light compaction," vol. 2720, no. December 1980. pp. 1-9, 1980.

[18] BIS, "IS 2720 Methods of Test for Soils: Part41 Measurement of Swelling Pressure of Soils." pp. 1-15, 1977.

[19] ASTM, "ASTM D-6276-99a:Standard test method for using pH to estimate the soil-lime proportion requirement for soil stabilization (withdrawn in July 2015)." 2006.

[20] BIS, "IS 2720 methods of test for soils:part 5 determination of liquid and plastic limit." pp. 1-16, 1985.

[21] BIS, "IS 2720 Methods of test for soils:part 6 determination of shrinkage factors," vol. 2720, no. July 1972. pp. 1-12, 1972.

[22] BIS, "IS 2720 methods of test for soils:part 40 determination of free swell index of soils," vol. 2720, no. March 1978. pp. 1-5, 1977.

[23] Indian Road Congress(IRC-37), "IRC 37:tentative guidelines for the design of flexible pavements.” IRC, New Delhi, India, pp. 1-95, 2012.

[24] BIS, "IS 1498 classification and identification of soils for general engineering purposes," vol. 1870, no. June 1972. pp. 4-24, 1970. 